PIOTR KITOWSKI (Gdańsk)

\title{
Zabójstwo rajcy Nowego nad Wisłą w 1731 roku. Z dziejów badań nad wczesnonowożytną praktyką sądową
}

Jedną z głośniejszych spraw kryminalnych w XVIII-wiecznym Nowem nad Wisłą było zabójstwo urzędującego rajcy Kaspra Langi ${ }^{1}$. Była ona o tyle sensacyjna, że nie chodziło w niej wyłącznie o zajmowaną przez zamordowanego funkcję publiczną, lecz przede wszystkim o towarzyszące jej okoliczności oraz jedną z osób uznanych za współwinną - małżonkę Langi, Mariannę i jej udział w tej zbrodni.

Kasper Langa pochodził z poważanej mieszczańskiej rodziny. Jej członkowie często pełnili służbę w magistracie, zajmując rozmaite urzędy, od ławników, sędziów i rajców, po najbardziej reprezentacyjne - burmistrza oraz wiceburmistrzów. Podobnie jak w wielu podobnych przypadkach (Czayków, Żorawskich [Żurawski], Klothów [Klodt], Kuczora, Grabowskich, Schenck czy Szczepańskich) działo się tak zwykle w drodze awansu na poszczególne stanowiska, a ich kariera trwała całymi latami oraz była łączona z wyuczonym zawodem, najczęściej kupca lub rzemieślnika². Jednocześnie zdarzało się, że na urzędach zasiadało kilku członków danego rodu. Tak też było u Langów. Ławnikiem, burmistrzem oraz długoletnim rajcą Nowego był ojciec zamordowanego, Kasper Langa senior. Drugą z funkcji sprawował aż do swojej

${ }^{1}$ W materiale źródłowym występuje nieraz jako Kasper (Kaspar, Gaspar, Gasper) Lenga lub Lęga. W ten sposób podpisywał się on i jego ojciec, zob. np. Archiwum Państwowe w Bydgoszczy [dalej cyt. APB], 196/23, s. 195; APB, 196/24, s. 12, 44, 75; APB, 196/25, s. 10; APB, 196/92, s. 89. Niemniej, w większości zapisów konsekwentnie stosowano zapis nazwiska Langa. To samo dotyczy innych członków jego najbliższej rodziny.

2 A. Pryłowski, Czy istnial patrycjat $w$ małych miastach? (Na przykładzie Nowego n. Wista I połowy XVIII w.), „Gdańskie Studia Humanistyczne”, R. XIII, 1970, nr. 7, s. 73-74 (Tabela 3. Rajcy $i$ ławnicy nowscy w latach 1727-1739; Tabela 4. Rajcy $i$ ławnicy nowscy $w$ latach 1750-1763); por. też idem, Gospodarka Nowego n. Wisła w latach 1662-1772. Problemy produkcji $i$ wymiany, Bydgoszcz 1978, passim. W odniesieniu do, zaliczanej podobnie jak Nowe do kategorii mniejszych miast Prus Królewskich Kościerzyny, zjawisko udziału poszczególnych rodów w elitach władzy analizował Józef Borzyszkowski (Patrycjat kościerski II połowy XVII w. (Przyczynek do dyskusji), „Rocznik Gdański”, t. XXXI, 1971, z. 1, s. 109-125). 
śmierci w trzeciej dekadzie marca 1730 r. (w wieku około 80 lat) ${ }^{3}$. W okresie działalności w samorządzie zajmował się m.in. sprawami kamlarii (np. 17021705, 1708), kilkukrotnie obierano go na opiekuna miejscowych sierot, jak również powołano na bejzecera bractw piekarskiego, rzeźnickiego i kowalskiego $(1708,1709,1711,1718-1719)^{4}$. Dwukrotnie żonaty ${ }^{5}$, pozostawił po sobie dwóch synów: pochodzącego z pierwszego małżeństwa, wspomnianego Kaspra i niepełnoletniego jeszcze w momencie śmierci ojca, a spłodzonego już z drugą małżonką, Antoniego (ur. po 1712 r.) $)^{6}$. Langa młodszy był kolejno ławnikiem (od 1719 r.), rajcą (od ok. 1723 r.), a w ostatnich lata życia - wice-

\footnotetext{
${ }^{3}$ Wpisy z ksiąg miejskich informują, że w 1701 r. miał 52 lata (APB, 196/87, s. 69), w 1710 r. lat 60 (APB, 196/88, s. 121), w 172373 (APB, 196/95, s. 58), w 172474 (APB, 196/95, s. 141), a w 172878 lat (APB, 196/96, s. 235). Zmarł po 23 marca 1730 r. Tego dnia zwrócił się do sądu o wydelegowanie dwóch ławników, którzy mieli spisać jego testament. W nim zapisał młodszemu synowi (Antoniemu) stodołę, szopę i łąkę za miastem, celem sprzedaży i pokrycia kosztów przyszłej edukacji. Dobra te wyłączył z masy spadkowej. Reszta dobytku miała pójść w równy dział. Obecny przy czynności Kasper Langa przypomniał ojcu o pozostałej części spadku po matce (220 fl.), a pierwszej żonie testatora, która nie została mu dotychczas wydana. W odpowiedzi ojciec poprosił go o rezygnacje z pozostałej części długu (APB, 196/97, s. 42). Pogrzeb starszego Langi odbył się 27 marca 1730 r. Został on pochowany w nowskiej farze, w reprezentacyjnym miejscu przy chórze, K. Kościński, Zapiski w księdze przychodu kościoła parafialnego w Nowem, „Zapiski Towarzystwa Naukowego w Toruniu”, t. 2, 1912, nr 8, s. 157 („Rok 1730. Martii 27. Pochowano pana Kaspra Lange w pierwszym chórze").

${ }^{4}$ W 1707 brał udział w konfiskacie dóbr mieszczan zbiegłych z Nowego w związku z niezapłaconą hiberną oraz był ekstraktorem czynszów. APB, 196/19, s. 61-64, 125, 136, 139, 253; APB, 196/20, s. 15-16, 29, 51, 102, 113, 129; APB, 196/88, s. 63.

${ }^{5}$ Pierwsza żona zmarła przed 30 września $1712 \mathrm{r}$. Wtedy wdowiec wystąpił o sporządzenie urzędowego inwentarza wspólnych dóbr, APB, 196/21, s. 24. Kolejne małżeństwo zawarł przed rokiem 1718, APB, 196/23, s. 66-67. Być może to właśnie w związku z nowym związkiem w październiku 1717 r. sprzedał swój dom Annie Grzęmpskiej (Grzępskiej?) za sumę 270 florenów, APB, 196/24, s. 75-76.

${ }^{6}$ Trzeci syn, Tomasz, zmarł przed 1724 r. (APB, 196/95, s. 217-218). Już na początku kwietnia 1730 r. Kasper zaczął regulować sytuację prawną spadku ojca. Wystąpił m.in. z żądaniem stwierdzenia legalności zakupu łąki, którą ojciec sprzedał rajcy Michałowi Zorawskiemu (Żurawski; 14 kwietnia) oraz arendy stodoły. Zorawski poprzysiągł czynność i przedstawił odpowiednie pokwitowania (APB, 196/97, s. 43-49). Langa nie zrezygnował również z należnych mu jeszcze z porcji macierzystej 100 florenów. Przed oblicze rady wzywał świadków, którzy słyszeli jak przed śmiercią jego ojciec wspominał nie o 120, a 220 florenach wakującej sukcesji. Przy okazji postanowił ściągnąć własne wierzytelności (APB, 196/97, s. 51-52, 82-84, 91-92, 104-105, 115-116, 122-124, 127-130, 140, 177-179, 183, 187-188, 191, 206, 208, 211-212). 30 czerwca 1730 r. zażądał od macochy, niejakiej Korczykowskiej, sądowej przysięgi, w której miała potwierdzić, że nie zataiła majątku po ojcu. Przedstawił przy tym dokładny wykaz rzeczy do poprzysiężenia. Sąd nakazał przyrzeczenie, odraczając je do następnej sesji i grożąc 10 grzywnami w razie niestawiennictwa strony. Na następnym terminie wdowa, choć jak sama zaznaczyła nie będąc zobligowana do przysięgi przed ukończeniem działu, przysięgę złożyła (APB, 196/97, s. 81-82, 92-93). Sam dział się nie zachował. Spośród członków rodziny Langa zamieszkujących w Nowem dysponujemy tylko inwentarzem pośmiertnym, działem spadkowym (APB, 196/75a, s. 2-4, 12-14; 18 lipca i 21 października 1668 r.) i testamentem (APB, 196/75, s. 679; 24 kwietnia 1668 r.) Katarzyny Oldaber (z d. Langa). Trudno natomiast ustalić dokładny stosunek pokrewieństwa łączącego ją z Kasprem Langą.
} 
burmistrzem $^{7}$. W tym samym czasie razem z ojcem zajmowali eksponowane stanowiska w magistracie, w którym przez co najmniej 7 lat obaj zasiadali jednocześnie ${ }^{8}$.

Informacje na temat zabójstwa rajcy, dokonanego 23 października $1731 \mathrm{r}$., rejestruje kilkadziesiąt różnych wpisów źródłowych. Przede wszystkim dokumentują je prowadzone w mieście i niezwykle ważne dla badań nad dziejami miasta księgi rady oraz ławy. Oprócz tego kilka ważnych dokumentów zawiera fragmentaryczny zbiór wypisów z miejscowych ksiąg sądowych. Uzupełniają one wiadomości z ksiąg niezachowanych. Są to zapisy odnoszące się nie tylko do samej zbrodni oraz okoliczności jej popełnienia, ale także różnych kwestii pobocznych, a wiążących się z jego śmiercią, od organizacji i przebiegu pogrzebu, po podział pozostałego po nim spadku. Zestawienie wszystkich rzuca światło zarówno na praktykę kryminalną małego miasta pomorskiego, jak i postępowanie władz w przedmiocie rozwiązywania majątków mieszczan w nim zamieszkujących. Jest to o tyle ciekawe, że z racji zachowania dużej części ksiąg możliwe jest prześledzenie losu sprawy od zabójstwa (a nawet wcześniej w odniesieniu do działalności samorządowej oraz zawodowej zamordowanego), po rok 1757, kiedy dokonał się ostateczny podział masy spadkowej. Wydaje się zadaniem uzasadnionym przybliżenie tej sprawy, tym bardziej że postulat badań nad praktyką sądową stosowania prawa w ujęciu makro- i mikrohistorycznym pozostaje wciąż aktualny 9 .

Wydarzenia związane z zabójstwem nie były pierwszym przypadkiem, gdy Langę napadnięto lub sam został oskarżony o pobicie. W okresie dwóch lat

${ }^{7}$ Do 1731 r. był również odpowiedzialny za dokończenie budowy miejscowego ratusza, rewizji dróg oraz mostów, APB, 196/26, s. 5 (9 stycznia 1730 r.). Po śmierci na tym stanowisku zastąpił go rajca Michał Jungnykiel, APB, 196/27, s. 7 (30 stycznia 1732 r.).

${ }^{8}$ W 1730 r. widniał jako wiceburmistrz. Oprócz niego magistrat tworzyli: Paweł Kloth (prezydent), Maciej Kraffert (sędzia), Andrzej Rowaldt (Rotwaldt; rajca), Kasper Langa senior (rajca) i Michał Żorawski (rajca). Ławnikami byli Jakub Kuczora, Tomasz Szczepański, Stanisław Kuczora, Kazimierz Czajka, Krzysztof Trytt, Michał Jungnykiel (starszy bractwa rzeźnickiego, APB, 196/27, s. 15) i Jan Suleński (dokooptowany do składu rady z woli starosty) (APB, 196/25, s. 67). Podobnie wyglądał układ władz miejskich w 1731 r., z tą jednak różnicą, że do ławy wszedł Michał Zawadziński oraz zastąpiony został zmarły Langa senior (APB, 196/25, s. 79). Zgodnie z protokołem roku 1732 r. funkcje publiczne pełnili: Paweł Kloth (prezydent), Tomasz Szczepański (burmistrz), Maciej Kraffert (sędzia i starszy bractwa szewskiego, 196/27, s. 30), Andrzej Rowaldt (rajca), Michał Żorawski (rajca) i Michał Jungnykiel (rajca). Do ławy weszli: Jakub Kuczora (cechmistrz), Kazimierz Czajka (podcechmistrz), Michał Zawadziński, Jan Cynka (podstarszy bractwa piekarskiego, APB, 196/27, s. 22) i Piotr Nyss (w tym samym roku wybrano go na kamlarza i kolektora miejskiego, APB, 196/27, s. 6). APB, 196/27, s. 1.W samorządzie działał również Michał Langa (1707), ławnik i członek bractwa krawieckiego, APB, 196/20, s. 61-62. W końcu lat 50. XVIII w. ławnikiem został syn Kaspra Langi (młodszego), Jan Urban. Szybko awansował i już od 1764 r. zasiadał w radzie, także jako burmistrz. Stanowisko to piastował dalej w $1772 \mathrm{r}$. Takich ambicji nie miał natomiast drugi z synów, Józef (M. Bär, Westpreussen unter Friedrich dem Grossen, Bd. 2, Leipzig 1909, s. 756 (Joannes Urbanus Langa).

${ }^{9}$ Zob. M. Mikołajczyk, Proces kryminalny w miastach Małopolski XVI-XVIII wieku, Katowice 2013, s. 11 i n. 
poprzedzających mord znajdujemy sporo wpisów, które informują o czynach zabronionych skierowanych przeciwko rajcy. Prawie dokładnie rok wcześniej, w listopadzie 1730 r., złożył on skargę przeciw Stanisławowi Kuczorze, pisarzowi (1716-1727), ławnikowi (1727-1738) i późniejszemu włodarzowi Nowego $(1739)^{10}$. W jej świetle Kuczora miał rzekomo napaść na dom Langi, grożąc mu przy tym nożem. Powodem ataku była kalumnia skierowana pod adresem żony pozwanego oraz zaległe sprawy sądowe, jakie strony toczyły od kilku lat. W późniejszym czasie jego domostwo naszła także małżonka pozwanego, która - zgodnie z protokołem - ,aktora wołała zelżywemi słowy od szelmów, złodziejów [...] y czarowników"11. Ostatecznie strony zawarły ugodę i zakończyły spór. 28 marca 1731 r. burmistrz poprosił o dokonanie obdukcji w związku z pobiciem go przez podchorążego nazwiskiem Marunda $(?)^{12}$. Do tej czynności zobligowano dwóch sądowych, wspomnianego Stanisława Kuczorę (!) i Michała Zawadzkiego. Wykazała ona niegroźne rany głowy i twarzy. Z kolei w maju 1731 r. Langę pozwał Tomasz Szczepański o „półgębek” (spoliczkowanie). W odpowiedzi na zniewagę pozwany uderzył ławnika w twarz, za co został zobowiązany do zapłaty 6 grzywien kary (3 dla sądu i 3 dla pokrzywdzonego). Jeszcze tego samego dnia złożono przeciw niemu skargę o bezpodstawne oskarżenie o kradzież oraz windykacje ruchomości bez wyroku sądu. Sędzia nakazał stronom ugodę i zapłatę po funcie wosku dla miejscowej fary „na chwałę Najświętszej [Marii] Panny”. Strona, która nie wykonałaby orzeczenia, miała zapłacić dodatkowo 30 florenów $^{13}$.

Jak się wydaje, żadna z powyższych spraw nie była bezpośrednio związana z jego zabójstwem. Z akt wynika, że sprawcą zbrodni był Józef Piątkowski, mieszkaniec wsi Zelgoszcz, położonej w starostwie gniewskim ${ }^{14}$. Oprócz tego wiemy o nim tylko tyle, że miał przybyć do Nowego z polecenia dwóch mieszczek gniewskich, niejakiej Skorzowskiej i Majewskiej, przyuczających go do rzemiosła krawieckiego, którym trudnił się również zamordowany. W samym mieście Piątkowski przebywał jednak - jeśli przyjąć zapis dokumentacji za wiarygodny - zaledwie $5 \mathrm{dni}^{15}$.

Zabójstwa nie dokonał jednak w Nowem. Morderca czekał na swoją ofiarę poza miastem, niedaleko karczmy, w leżącym na drodze do Gniewu, Bochli-

${ }^{10}$ P. Kitowski, Notarius civitatis w kancelarii miejskiej Nowego n. Wisła $w$ XVIII wieku, passim [w druku, „Studia z Dziejów Państwa i Prawa Polskiego”].

${ }^{11}$ APB, 196/97, s. 148-149.

${ }^{12}$ Ibidem, s. 176.

${ }^{13}$ Ibidem, s. 186-190. Niedługo po zabójstwie pojawiła się plotka, że stał za nim ławnik Nowego Kazimierz Czayka. Za tę kalumnię pozwał przed sąd Wojciecha Ogórkowskiego, który zaprzeczył, że sugerował jego udział w zbrodni. Fakt ten poprzysiągł. Z kolei Czayka rzekomo rozpowiadał, że Ogórkowski cudzołożył z żoną Langi (APB, 196/97, s. 319-321, 336).

${ }^{14}$ APB, 196/114, s. 72.

${ }^{15}$ Ibidem, s. 74-75. Być może był spokrewniony z mieszkającą w Nowem rodziną Piątkowkich, małżeństwem Janem i Konstancją (z d. Nochowicz). APB, 196/25, s. 82. 
nie. Tam spędził co najmniej 2 dni. W końcu, gdy Langa zjawił się na miejscu, z pożyczonej rusznicy postrzelił go w głowę, a leżącego na ziemi dobił. Działał $\mathrm{z}$ bezpośrednim zamiarem pozbawienia życia. Zbrodnię zaplanował i wykonał w brutalny sposób: „[Piątkowski - P. K.] niemiłosiernie zabił, nie tylko zraniwszy głowę y twarz, lecz całą głowę, jak na miazgę zbiwszy"16. Zgodnie $\mathrm{z}$ wykonywanym $\mathrm{w}$ takich sytuacjach protokołem obdukcji, denat miał liczne obrażenia: ranę nad prawym uchem,

„Z tyłu [głowy - P. K.] ranę długą na ćwierci głęboką aż do ust, kości całe pogruchotane w głowie, aż sztuki głowy leżą na nosie, ranę długą na dwa cale aż do oka lewego, głęboką do kości na głowie nad czołem ranę długą na trzy cale od cięcia, nad lewym uchem ranę ciętą długą na trzy cale, niżej lewego ucha długą na ćwierci, kości w głowie cale potłuczone y zgruchotane"17.

Po dokonanej zbrodni Piątkowski zbiegł z miejsca zdarzenia, znajdując azyl pod protekcją księdza nazwiskiem Czarnecki. W tym czasie ustalono osobę sprawcy i, po schwytaniu, przewieziono go do Gniewu, gdzie był tymczasowo przetrzymywany. W konsekwencji udowodnionego mu czynu orzeczono wobec niego karę śmierci ${ }^{18}$. Wyrokiem sądu miał zostać ścięty, przed czym kat winien był mu obciąć wpierw prawą rękę na znak popełnionej zbrodni. Dodatkowo, wszystkie jego dobra, zarówno te znajdujące się w Zelgoszczy, jak i gdziekolwiek indziej, przeszły na rzecz dzieci zamordowanego oraz ich matki.

Początkowo niejasny był udział w sprawie żony burmistrza, Marianny Langi. Córka bogatego sołtysa gętomskiego, a jednocześnie zięcia sędziego klucza pelplińskiego, Kazimierza Długońskiego ${ }^{19}$, od początku była aktywną stroną w postępowaniu, wnioskując o kolejne czynności sądowe (obdukcja, inwentaryzacja spadku $)^{20}$. Twierdziła, że nic nie wiedziała o planach Piątkowskiego i nie miała z zabójstwem nic wspólnego. Niebawem wyszły jednak na jaw fakty, które podważyły to stanowisko. Wdowa miała utrzymywać bliskie kontakty ze sprawcą i na domiar złego korespondować już po zabójstwie z ciotkami, prosząc o jego ukrycie - „aby go mogły ochronić, żeby do klasz-

${ }^{16}$ APB, 196/114, s. 72

${ }^{17}$ Obdukcji dokonał cyrulik Jakub Heyna, w obecności dwóch sądowych (nie wymienionych z nazwiska w protokole czynności). Relację z niej przedstawiono następnie sędziemu, APB, 196/97, s. 286. Podobne obdukcje przeprowadzone przez ławników Nowego: APB, 196/106, s. 124-125 (1751), APB, 196/107, s. 5-6 (1747).

${ }_{18}$ APB, 196/97, s. 290-291 (protokół przesłuchania świadków).

19 Jej brat Leonard Długoński był kornowskim profesem. Duchownym był również drugi z braci, Kazimierz, który wstępując w 1728 r. w stan duchowny, legował siostrze i szwagrowi całą przypadającą na niego w przyszłości część spadku po matce. Na początku kolejnego roku zapis został potwierdzony w księgach miejskich (APB, 196/96, s. 138-139, 413).

${ }^{20}$ APB, 196/25, s. 90, 124. 
toru albo do żołnierzy y onego wyprowadziły"21. Tyle wystarczyło staroście, by ten zlecił uwięzienie kobiety. Podczas kolejnych przesłuchań podtrzymywała ona swoją wersję. Nie mając świadków, którzy mogliby potwierdzić jej niewinność, próbowała przekonać sąd do oczyszczenia przysięgą 22. Prośbę odrzucono, postanawiając oddać ją w ręce instygatora. Ten jednak, ku zdumieniu prowadzących śledztwo - odmówił ${ }^{23}$, wykazując nieposłuszeństwo wobec rady i składanego w momencie objęcia funkcji przyrzeczenia ${ }^{24}$. W odpowiedzi starosta wysłał własnego człowieka, uczciwego Andrzeja Krystka, który w jego imieniu miał zająć się sprawą. W odróżnieniu od poprzednika, instygator zamkowy przystąpił do wykonania obowiązków.

Ustalono, że Langowa prawdopodobnie już wcześniej planowała pozbycie się męża. Razem z bratem i inną kobietą miała zamiar go otruć lub zlecić jego zabójstwo. Jeszcze 18 grudnia 1730 r., a więc 10 miesięcy przed popełnieniem zbrodni, Kasper Langa przedstawił radzie Nowego list:

„Wielce M[iłoś]ci[wa] Pani. Już też widzę nie rozkosz Twoją, już też chyba bym ja nie był bratem Twoim, żebym Ci nie pomógł. Będę pilnować przysięgę Bogu [daną - P. K.], tylko miej w pogotowiu fuzję, żebym jej nie pożyczał, powtóre gospody, abym tam miał gdzie tę noc nocować [...], żebym miał i co jeść, a niech mnie Bóg skarze jeżeli zadość nie uczynię, już mi nigdy wierzyć nie będziesz, ani bliskim znać mię nie będziesz przyjacielem, jeżeli tego nie zrobię, a odchodząc, będę niech w pierwszym stępie nogę złamię. Teraz mi wierz Kochana M[oś]ci Dobrodziejko zostaje" 25 .

Brak w nim co prawda danych pozwalających na jednoznaczną identyfikację nadawcy i adresata, aczkolwiek z treści oraz późniejszych zdarzeń można wnioskować, że korespondowała Marianna Langa z Piątkowskim (lub swoim bratem). Z tego faktu nie wyciągnięto wniosków, gdyż nie posiadamy jakichkolwiek śladów wskazujących na to, żeby cokolwiek w tej sprawie zrobiono. Wydaje się też, że sam zainteresowany, Kasper Langa nie podejmował w związku z nią dalszych kroków prawnych. Nie był to jedyny dowód. Langową pogrążył sam Piątkowski. Podczas tortur przyznał, że dokonał zbrodni za namową przyszłej wdowy:

${ }^{21}$ APB, 196/27, s. 5; APB, 196/26, s. 3.

${ }^{22}$ APB, 196/27, s. 4.

${ }^{23}$ APB, 196/114, s. 71 (,Instygator nie wiedzieć z jakiej przyczyny nie chciał dochodzić niewinnie wylanej krwi ucz[ciwego] P[ana] Langi y odstąpił od sądu”).

24 Wzór przysięgi instygatorskiej z 1754: „Jurament Instygatora Gotarda Litkamera: Ja N. p[rzysięgam] Panu Bogu Wszechmogącemu w Trójcy Ś[więtej] Jedynemu, iż na Urzędzie moim będący, w sprawach które do mnie należeć będą, szczery, wierny, pilny być chce, y jak najlepiey będę mógł promować, bronić, y utrzymywać zechce, tak w Radzie jako y w Sądach Ławniczych y Tertii Ordinis. Tak mi P[anie] Boże dopomóż”, APB, 196/32, s. 134.

${ }^{25}$ APB, 196/26, s. 94. 
„Z inquizycji pokazuje się, [...] iż gdy pilnować na niego [Kaspra Langę - P. K.] odchodził do Bochlina, do niej kryjomo na noc przyszedł, o zabiciu nieboszczyka Langi namawiali się".

Przy okazji Langowa miała go poić winem oraz dostarczyć narzędzie zbrodni - rusznicę pożyczoną od sąsiada. Do tego dała mu proch z kulami, które tak jak w wypadku broni pożyczyła. Ponadto po zabójstwie wystosowała wspomniany list do ciotek w Gniewie, prosząc je o ukrycie sprawcy. Został on ujawniony w postępowaniu i, wydaje się, że przekonał ją do przyznania się do winy.

Prawo chełmińskie rozróżniało podstawowe formy zjawiskowe popełnienia przestępstwa, nie posługując się przy tym jednolitą terminologią ${ }^{26}$. Stąd wkład w nie wdowy mógł zostać podciągnięty pod spisek, pomocnictwo lub podżeganie do zabójstwa. W Nowem jako podstawę orzekania stosowano równocześnie Rewizje nowomiejska $(1580)^{27}$ i toruńska $(1594)^{28}$. Podług tej ostatniej, spisek oznaczał rozmyślne działanie kilku osób, udzielających sobie wzajemnie pomocy, w celu zamordowania innej osoby ${ }^{29}$. Dla każdego uczestnika przewidziana była za to kara główna - śmierci. Podżeganie polegało generalnie na namowie bezpośredniego sprawcy do popełnienia czynu zabronionego. Podżegacz odpowiadał w granicach odpowiedzialności sprawcy. Ostatnia $\mathrm{z}$ form - pomocnictwo, wiązała się $\mathrm{z}$ pomocą sprawcy $\mathrm{w}$ dokonaniu przestępstwa $^{30}$. Teoretycznie pomocnikowi groziła taka sama kara jak mordercy. Bardziej szczegółowe dywagacje są tu jednak zbędne, jako że granica między wszystkimi formami na gruncie ówczesnych rozwiązań prawnych była niejednokrotnie płynna i de facto w praktyce kwalifikacja prawna czynu i wymiar kary zależały głównie od uznania oraz oceny konkretnego składu sędziowskiego. Wszystko sprowadzało się w tym wypadku do tego, czy Langowa miała zapłacić za swój występek głową czy też nie, oraz czy straci prawo do majątku po mężu. Drogę do utraty dóbr otwierały zarówno przepisy karne, jak i cywilne. Już Prawo starochetmińskie z 1394 r. ${ }^{31}$, a za nim rewizje, dość jasno stanowiły, że żona, której udowodniono zbrodnię, ,traci [...] majątek s. $35-38$.

${ }^{26}$ D. Janicka, Prawo karne w trzech rewizjach prawa chetmińskiego z XVI wieku, Toruń 1992,

${ }^{27}$ Rewizja nowomiejska prawa chetmińskiego 1580 (1814) zwana także ius culmense emendatum lub ius culmense polonicum, pod red. Z. Zdrójkowskiego, przekład I. Malinowska-Kwiatkowska, J. Sondel, Toruń 1993 [dalej cyt. RN].

${ }^{28}$ Ius Culmense ex ultima revisione oder das vollständige Kulmische Recht, wyd. M.C. Hanow, Danzig 1767 [dalej cyt. JC].

${ }_{29}$ JC, s. 231 (V II, 7, 9); D. Janicka, Prawo karne w trzech rewizjach, s. 36.

${ }^{30}$ RN, s. $50(\mathrm{~V}, 50)$.

31 Prawo starochetmińskie 1584 (1394), pod red. W. Maisla, Z. Zdrójkowskiego, przekład A. Bzdęga, A. Gaca, Toruń 1985, s. 70 (art. 37: „O podżeganiu albo morderstwie dokonanym przez niewiastę na jej ślubnym mężu”). 
należny po mężu, a majątek winni otrzymać spadkobiercy męża"32. W świetle Rewizji nowomiejskiej kobieta, która nastawała na życie męża, mogła stracić - jako dziedzic niegodny - prawo do majątku po nim. W efekcie nie partycypowała w schedzie, tak jakby nie dożyła otwarcia spadku ${ }^{33}$.

Nie znamy motywu lub motywów kierujących oskarżoną. Z krótkiej notki zamieszczonej w aktach sądowych możemy ustalić, że skazano ją na śmierć.

W uzasadnieniu z 11 stycznia 1732 r. czytamy:

„nie tylko poprzysiężonej wiary i miłości małżonkowi swemu nie trzymała, lecz jeszcze do śmierci jego pomocnicą była, aby na gardle karana była niniejszym dekretem nakazuje" 34 .

Zastrzeżono natomiast, aby jeszcze w tym samym tygodniu ,poprzysiężona była" do wszystkich zarzutów, po czym dopiero wyrok miał zostać wykonany. Dodatkowo, ponieważ nie miała wkładu we wspólny majątek, a wręcz przeciwnie, rzekomo marnotrawiła dobra, całość przypadła dzieciom nieboszczyka, co zresztą przewidywały przytoczone wyżej przepisy prawa. Dotyczyło to zarówno sierot z jej pierwszego małżeństwa, jak i tych spłodzonych już z rajcą. Sam dział spadku po Kasprze Landze nastąpił kilka dni po egzekucji, 17 stycznia $1732 \mathrm{r}$.

Śmierć wdowy nie zakończyła sprawy. Krąg oskarżonych został poszerzony, jako że winy dopatrywano się również u rodziców skazanej. Z napisanego do córki listu wynikało jasno, że wiedzieli o planowanym zabójstwie, lecz nie powiadomili ani swojego zięcia, ani tamtejszych władz miejskich, co mogłoby zapobiec tragedii. Za to mieli odłożyć 120 grzywien na rzecz miejscowej fary (sądowemu ,za duszę nieboszczyka Langi na msze święte y na jaką pamiątkę w kościele"), kolejne 90 instygatorowi i 30 dla sądu ${ }^{35}$. W sumie zatem 240 grzywien $^{36}$. Do rozwiązania pozostała jeszcze kwestia wcześ-

${ }^{32}$ RL, s. 128 (art. 35).

${ }^{33}$ RN, s. 91-92 (III, 47); P. Kitowski, Sukcesja spadkowa $w$ świetle rewizji prawa chetmińskiego (1566, 1580 i 1594 r.), [w:] Pro memoria. Księga dla uczczenia pamięci Profesor Krystyny Kamińskiej, pod red. A. Gacy, Toruń 2013, s. 176-177.

${ }^{34}$ APB, 196/114, s. 73.

35 Ibidem, s. 74.

${ }^{36} \mathrm{Na}$ marginesie można dodać, że teść zmarłego, Kazimierz Długoński był równocześnie jego głównym wierzycielem. Langa był mu winien sporą jak na warunki Nowego kwotę 800 florenów (nie wliczając odsetek w wysokości 6\% od kapitału). W świetle wyroku z 3 marca $1730 \mathrm{r}$. dłużnik został zobowiązany do uregulowania długu w ciągu 12 tygodni, czego do lipca 1731 r. nie zrobił, gdyż jak sam twierdził „Pan Bóg nawiedził [go - P. K.] w fortunie”. Rajca nie wdał się w sprawę i nie stanął na wyznaczony termin. W końcu strony umówiły się, że na poczet długu Długońskiemu zostanie zapisana włóka wraz z wystawionym na niej budynkiem gospodarczym i zasianym zbożem. Po śmierci teścia, wdowa Ewa Długońska (w grudniu 1734 r.) sprzedała ją za 500 fl. Kazimierzowi Czayce. APB, 196/97, s. 36-37, 221-222; APB, 196/25, s. 90-91,124-125. 
niejszych planów pozbycia się rajcy. Brak jednak w źródłach dowodów na to, że wytoczono osobny proces bratu skazanej bądź innym osobom.

Pogrzeb Langi odbył się, gdy zakończono postępowanie przeciw wdowie i podzielono jego majątek, a więc pod koniec stycznia 1732 r. (po 26 stycznia) $)^{37}$. Towarzyszyła mu procesja $\mathrm{z}$ wyprowadzeniem ciała, przy udziale przedstawicieli miejscowych bractw. Jako że w majątku nieboszczyka nie pozostało wiele gotówki, aby opłacić pogrzeb, rada musiała zlecić sprzedaż należącego do spadku inwentarza zwierzęcego ${ }^{38}$. Nie obyło się też bez incydentów. Podczas uroczystości doszło do zelżenia członków cechu rybackiego. Zostali oni zaproszeni na pogrzeb, by zwyczajowo nieść kierce. Zarówno na ulicy, jak i wcześniej w swoim domu, sędzia miasta łajał ich niewybrednymi słowami, nieprzystającymi do urzędu oraz osób, które obraził. Dodatkowo, już po ceremonii, dziękując poszczególnym bractwom, pominął rybackie. Sołtys tłumaczył się później, że nie zelżył rybaków, tylko chłopów, którzy szli w kondukcie i nieśli kierce - jego zdaniem - „w nieporządku”. O jego nastawieniu do bractwa miał świadczyć fakt, że zezwolił jego członkom stanąć bezpośrednio przy trumnie. Ostatecznie skarga została oddalona, jako że wcześniej magistrat specjalnie powołał sołtysa do dbania o właściwy przebieg procesji i porządek w pochodzie. Obie strony miały się wzajemnie przepro$\operatorname{sic}^{39}$. Nie zadowoliło to cechu, który szukając sprawiedliwości, postanowił skorzystać z apelacji i wystąpić ze swoją sprawą do starosty.

Po pogrzebie należało jeszcze uregulować ostatnie kwestie spadku po Landze oraz trwale zabezpieczyć byt sierot. Żadne z trójki jego dzieci (Kunegunda, Jan Urban i Józef) nie było na tyle samodzielne, by zostać głównym spadkobierca. Nie byli tym także zainteresowani ich tymczasowi opiekunowie. By więc zapobiec pogorszeniu stanu nieruchomości, rada podjęła decyzję o ich oddaniu $\mathrm{w}$ arendę. $\mathrm{Z}$ takim wnioskiem wystąpił na początku lutego gdański kupiec Beniamin Maki (wpis do ksiąg datowany na 31 stycznia i 1 lutego 1732 r. $)^{40}$. Zaproponował on, że weźmie w dzierżawę domostwo nieboszczyka, wszystkie grunty oraz gorzelnię, dla chcącego zamieszkać w Nowem Michała Szpyca (Spetz/Spitz), za kwotę 200 florenów ${ }^{41}$. Rada oraz opiekunowie, widząc w tym możliwość zachowania spadku w całości, wyrazili zgodę. Zaznaczono przy tym, że arenda będzie trwała rok (od zapustów roku 1732 do zapustów roku następnego), zaś hiberną nie będzie obciążony nowy posesor, a majątek dzieci zmarłego. Co zrozumiałe, Szpyc został dodatkowo zobowią-

\footnotetext{
${ }^{37}$ APB, 196/27, s. 6.

${ }^{38} \mathrm{Na}$ wniosek sędziego miejskiego 3 grudnia $1731 \mathrm{r}$. oszacowano należące do zmarłego wieprze, które trzymał przy gorzelni. 26 stycznia 1732 r. komisja taksatorska wyceniła konie (w sumie 3 sztuki - 57 florenów) i krowy (2 sztuki - 36 florenów). APB, 196/97, s. 289, 316.

${ }^{39}$ APB, 196/27, s. 19-20.

${ }^{40}$ Ibidem, s. 8, 12.

${ }^{41}$ A. Pryłowski, Czy istniat patrycjat w małych miastach?, s. 73.
} 
zany do właściwego dbania o nieruchomości i wydany mu sprzęt domowy, tak by nie uległy dewastacji ${ }^{42}$. Były one wolne od jakichkolwiek obciążeń miejskich przez kolejne 3 lata $^{43}$. Oficjalnie Szpyc został przyjęty do prawa miejskiego 27 lutego, pokazując list rodowy i składając zwyczajową przysię$\mathrm{geq}^{44}$. Oprócz tego, jeszcze w 1732 r., wyarendowano włókę Langi. Objął ją popierany przez nowskiego starostę Jakuba Zboińskiego, Wojciech Ogórkowski $^{45}$.

Nad przestrzeganiem warunków arendy mieli czuwać przede wszystkim powoływani na miejsce rodziców tutorzy. W krótkim czasie okazało się, że dzierżawca nie miał zamiaru dotrzymać umowy i przestał płacić ustalone w kontrakcie sumy, wymyślając kolejne wymówki. Problem był istotny, tym bardziej że do magistratu zaczęły spływać prośby wierzycieli o wypłacenie należnych im od zmarłego długów ${ }^{46}$. Jednym $\mathrm{z}$ wierzycieli było same miasto, gdyż, jak obliczono, poszukiwania Piątkowskiego oraz jego późniejszy areszt kosztował Nowe 120 florenów ${ }^{47}$. $Z$ racji, iż wartość spadku nie pozwalała na szybkie uregulowanie wszystkich żądań, kredytorom nakazywano cierpliwość, a opiekunom szybkie spłacenie zobowiązań. Biorąc więc pod uwagę sytuację majątku, postanowiono oddać go w kolejną arendę. Nowym dzierżawcą został niejaki Artman (Hartman?). Niebawem wyszło na jaw, że i on nie miał zamiaru realizować umowy. Dobra przekazano mu w 1733 r., a już w maju roku następnego do rady trafiła skarga Tomasza Szczepańskiego, który twierdził, że Artman nie chce zajmować domostwa Langów, zaś z przyrzeczonych 52 florenów zapłacił tylko połowę ${ }^{48}$. Ten $\mathrm{z}$ kolei wyraził chęć realizacji umowy, lecz z uwagi na „czas ciężki” prosił o możliwość zwłoki w zapłacie. Wobec tego magistrat zdecydował obniżyć mu kwotę arendy do 40 florenów. Warunkiem było, żeby niezwłocznie zamieszkał w domu. Było to jednak roz-

42 ,Jednakże domostwo powinno być w dobrej konserwacyi y porządku, aby nie przyszło w dezolacyę y ruinę. Także y to co będzie w domostwie z ruchomych rzeczy panu Arendarzowi oddane, aby też było w całości powrócone, jako też w gorzelni, według specyfikacji sławetnych panom opiekunom. Przy sadzie y ogrodzie płoty jakie odbierze, żeby takie powrócił”. APB, 196/27, s. 12-13.

${ }^{43}$ Zgodnie z postanowieniami edyktu z 1714 r. regulującego kwestie budowlane w mieście.

${ }^{44}$ APB, 196/27, s. 22.

${ }^{45}$ APB, 196/97, s. 337-338. Po objęciu gruntu arendarz uskarżał się, że została „zdezelowana” przez Kazimierza Czaykę. Broniąc prawa do użytkowania, zelżył tego drugiego, za co sąd nakazał mu odłożenie 13 grzywien do kościoła, 7 na cmentarz oraz kolejnych 6 na znajdujący się na przedmieściu szpital.

${ }^{46}$ Przykładowo, Jan Cynka żądał zwrotu pożyczonych Landze krótko przed śmiercią (24 października 1731 r.) ponad 20 korców żyta. Nie chciał przy tym, aby zwrot był dokonany w naturze, lecz w pieniądzu, szacując jeden korzec na 2 floreny (łącznie 40 złotych). Na to nie zgodziła się rada, uznając, że spełnienie świadczenia powinno nastąpić w zbożu, ponieważ to w nim udzielono pożyczki. APB, 196/28, s. 34-35; APB,196/27, s. 25-26 (sprzedaż łąki przejętej za dług o wartości 50 florenów, 22 marca 1732 r.).

${ }^{47}$ Kwota ta miała być pokryta przez teściową denata ze sprzedaży włóki, APB, 196/25, s. 125.

${ }^{48}$ APB, 196/29, s. 51. 
wiązanie tymczasowe. Cztery lata później, w październiku 1738 r., tutorzy nie widząc innego rozwiązania, zdecydowali się wystąpić do rady o zgodę na sprzedaż części dóbr. Dom razem ze stajnią miał zostać sprzedany, za jedyne 57 florenów, mieszczaninowi Antoniemu Klementowiczowi ${ }^{49}$. Ich zdaniem, dalsze utrzymywanie ówczesnego stanu doprowadziłoby tylko do całkowitej ruiny budynków, spadku ich wartości, a tym samym szkody dla sierot. Pewniejsze miało być zainwestowanie uzyskanej kwoty i zapewnienie dzieciom środków utrzymania. Nie mając innego wyjścia, przystano na to. Strony ustaliły przy tym, że przy sprzedaży Klementowicz zapłaci tylko 20 florenów. Resztę rozłożono na raty: druga (20 florenów) była wymagalna na Zielone Świątki roku 1739 i trzecia (17 florenów) przed Bożym Narodzeniem tego samego roku. Zastawy na łąkach Langi kupujący zobowiązał się do wykupu własnym sumptem. Zaznaczono przy tym, że po wypłaceniu pełnej kwoty, opiekuni powinni wystawić Klementowiczowi odpowiednie potwierdzenie, które potem miało się znaleźć w księgach sądowych i zabezpieczyć go przed roszczeniami w przyszłości.

Nie zakończyło to jednak kwestii spadku. Po latach, w marcu 1750 r., najmłodsza z sierot, Kunegunda, za pośrednictwem swoich opiekunów ${ }^{50}$ prosiła o ponowną specyfikację dóbr, uważając, że nie wszystko zostało zaliczone w poczet schedy ${ }^{51}$. Pozew skierowany był przeciw jej braciom - Janowi Urbanowi i Józefowi ${ }^{52}$. Co ciekawe, uczyniła to ponad 18 lat po śmierci ojca i 17 od działu (17 stycznia 1732 r.). W odpowiedzi bracia pokazali ugodę, którą w imieniu sierot podpisali ich tutorzy. Sąd wyraził zgodę na powtórny dział, nakazując jednocześnie, aby w tej sprawie wzięli udział mediatorzy. Termin czynności wyznaczono dość ogólnie - do świąt Wielkiej Nocy. W tym czasie Langowie mieli łożyć na siostrę po 2 floreny na bieżące wydatki. Do ostatecznego rozliczenia między rodzeństwem doszło dopiero 7 lat później, w kwietniu $1757 \mathrm{r}^{53}$ Zgodnie z ugodą Kunegunda otrzymała udział w spadku wynoszący 250 florenów i kolejne 50 tytułem prowizji od tej kwoty. Suma była zapisana na dobrach Józefa Langi, który finalnie wypłacił ją do rąk opiekunów, otrzymując $\mathrm{w}$ zamian odpowiednie poświadczenie zapłaty. W następnym roku zamężna już Kunegunda pozwała przed oblicze rady swoich tutorów ${ }^{54}$. W jej

${ }^{49}$ APB, 196/25, s. 182-183; APB, 196/30, s. 51.

${ }^{50}$ Ławnika Jana Klotha i starszego gminu Jana Cynki.

${ }^{51}$ APB, 196/31, s. 29-30.

52 Jan Urban Langa był ławnikiem Nowego w latach 1759-1763 (A. Pryłowski, Czy istniat patrycjat w małych miastach?, s. 73-74). Po raz pierwszy pojawił się w samorządzie przy okazji wyborów na ekstraktora hiberny w 1750 r., na którą funkcję powołano go razem z Janem Cynką (APB, 196/31, s. 7). W 1749 r. zakupił od burmistrza Nowego, Franciszka Jakubowicza dom za 100 florenów. Umowy jednak nie dotrzymał. W 1753 r. został pozwany o zaległe świadczenie (APB, 196/32, s. 67-68).

${ }^{53}$ APB, 196/33, s. 180-181.

${ }^{54}$ APB, 196/34, s. 142-143. 
imieniu stanął małżonek, Józef Żorawski ${ }^{55}$, żądając od Klotha, wtedy już sędziego miasta, i Jana Cynki, ówcześnie ławnika, rachunków z dokumentacją ze sprawowanej opieki. Obowiązek ten potwierdził sąd, który w razie braku rozliczenia, groził im karą w wysokości 15 grzywien. Z racji braku reakcji, podniesiono jej wysokość do 30 grzywien. Przedmiotem sprawy nie była jednak sama opieka i wydatki z nią związane, ale, jak wynika z dokumentacji, także kwestia wartości udziału żony protestanta, jaki wcześniej otrzymała ${ }^{56}$. Finału akurat tego aspektu sprawy nie znamy.

${ }^{55}$ Ławnik w latach 1750-1757. Od 1759 do 1763 r. rajca Nowego.

${ }^{56}$ APB, 196/34, s. 145. 